\title{
Legal Representation for the Extrauterinely Conceived Person from the Roman Tradition to the Law of New Technologies
}

\author{
Susana Isabel Estrada ${ }^{1,2}$ \\ ${ }^{1}$ Faculty of Law and Social Sciences, National University of Tucumán, Tucumán, Argentina \\ ${ }^{2}$ Faculty of Political, Social and Juridical Sciences, Catholic University of Santiago del Estero, Santiago del Estero, Argentina
}

Email address:

Siecs2004@yahoo.com.ar

\section{To cite this article:}

Susana Isabel Estrada. Legal Representation for the Extrauterinely Conceived Person from the Roman Tradition to the Law of New Technologies. American Journal of Applied Scientific Research. Vol. 6, No. 1, 2020, pp. 1-12. doi: 10.11648/j.ajasr.20200601.11

Received: January 14, 2019; Accepted: September 5, 2019; Published: February 19, 2020

\begin{abstract}
The person of the conceived child, whatever is the place of gestation, will be the object of analysis in Roman sources, in Argentine legislation, in some international rules and recent decisions of national, foreign and international courts. Our position will be based on absolute respect for human life from its beginning at conception, wherever it takes place, to its natural end, open to new realities but, at the same time, alert to everything that may be detrimental to the essential dignity of man when scientific or technological development is empty of moral values. The sudden advance of medicine and biology gave some alternative answers to the difficulties couples go through due to sterility, thus opening new horizons in this field. Hence, such investigations should be encouraged while respecting the intrinsic dignity of the human person. An approach to this issue involves deep bioethical options, since it demands respect for the autonomy of the parents' person, as long as in that exercise dignity, equality, or the rights of the extrauterinely conceived person are not violated, because you should not lose sight of the first reason: the right is of the child to be born and not of the parents to have or not to have a child, and it can never be invoked putting the life or the health of the most defenseless human being at risk. These practices cause more alarm than hope because everything technically possible is not, for that unique reason, ethically acceptable. Scientific progress should be oriented towards a direction that is truly fruitful and beneficial for humanity; and precisely of these new practices you do not have such certainty.
\end{abstract}

Keywords: Nasciturus, Representation, Advances, Science

\section{Introduction}

The person of the conceived child, whatever is the place of gestation, will be the object of analysis in Roman sources, in Argentine legislation, in some international rules and recent decisions of national, foreign and international courts.

The focus will be based on absolute respect to human life from its beginning at the conception, whatever is the place where it occurs, to its natural end, open to new realities but, at the same time, alert against everything that could be detrimental for man's essential dignity when scientific or technological development is empty of moral values [1].

Hence, research tending to find alternative questions to mitigate sterility by opening new ways should be encouraged, human person's intrinsic dignity always being respected. As regards this point, Hans Jonas used to say:

"For the sake of human autonomy, of the dignity it demands, that we possess ourselves and we do not let ourselves be possessed by our machine, we have to put the technological gallop under extratechnological control" [2].

The irruption of new technologies and scientific development without limitations that have their influence on human procreation, incites more alarm than hope. Scientific progress should be oriented towards a fruitful and beneficial direction for humankind, but precisely in these new practices there is no certainty. In the first century B. C., Cicero alerted on the transformations that might experiment the human mind.

"[...] if there is no one who prefers death to be transformed into an animal of any species, although in metamorphosis it 
could withhold the mind of a human being, the more miserable is to possess the mind of a wild beast while preserving at the same time the human shape! The more superior, then, is, in my opinion, the mind with respect to the body [...]" [3].

\section{Problem Statement}

The problems that technology development raises to Law are intricate and thorny so Law should be attentive to social changes in order to fulfill the purposes assigned to it in every social organization and to give answers in due time, because it will otherwise not keep control or social peace.

Over time, scientific community has tried to find alternatives to the difficulties couples go through because of sterility. The sudden advance of medicine and biology from the second half of the 20th century has given some answers to such problems, by opening new horizons. Hence, those investigations should be encouraged by respecting the intrinsic dignity of the human person.

The approach to this topic implies deep bioethical options, since it demands respect for the autonomy of the parents' person provided that in this exercise you do not injure either dignity, equality, or violate the rights of the person conceived through an extrauterine via, because you should not lose sight of the first reason: the right belongs to the child to be born and not to the parents to have or not to have a child, and it can never be invoked putting the most defenseless human being's life or health at risk.

If the child to be born is a person respect to his/her mother, he/she is not just that, but also and, fundamentally, he/she is a child and this condition that for his/her parents implies not only rights but also duties, changes the perspective completely.

[...] Nobody can validly consent to kill a human being, not even his/her mother who must not decide on a life that does not belong to her, not even when she finds herself in conflict with her own life [4].

These practices that bring hope and enthusiasm to the persons involved in situations of infertility, at the same time cause alarm and uncertainty because everything technically possible is not, for this unique reason, ethically acceptable. Scientific progress should be oriented towards a direction to be really productive and beneficial for humanity; and precisely of these new practices you do not have such certainty.

\section{Brief History of Assisted-Procreation Techniques}

The natural need to be projected through one's descendants led to the habit that from Old Greece and Roman Imperial times, mechanisms were begun to be sought in order to solve the problem of sterility. For this reason, from those pristine times attempts for animal artificial procreation occurred.

In the 2 nd century A. D., the Greek orthopedic doctor,
Sorano of Ephesus collected information concerning gynecology and obstetrics, based on human dissection. He knew the position of the uterus and advised to occlude it with ointment and fatty substances during copulation to avoid conception, which denotes certain knowledge of the mechanisms of human fertilization. Sorano declared himself an enemy of mechanical abortion and said that embryotomy was a practice used for the most urgent cases. By that time, they were teachings of inestimable value in the field of tocogynecology of the maximum exponent of the Methodical School.

One of the first experiments took place in the 16th century when Marcelo Malpighi, an investigator on histology and microscopic anatomy, experimented on silkworms. Then, in the 17th century, Abbot Lazaro Spallanzani experimented on canines and began the first investigations on sperm freezing.

In the 19th century the first results were obtained in human beings. The first found antecedent dates from 1790 when Thouret managed to remedy his wife's infertility by injecting his own seminal fluid. Then, scientists Hunter in 1864 and Marion Sims in 1866 carried out artificial homologous inseminations [5]. The latter performed fifty-five inseminations to half a dozen women, obtaining as a result only one pregnancy that had to be aborted, which was kept secretly in those times. In 1884 Panscoast carried out the first heterologous insemination, and from that time the method has taken off in practice and in medical literature. In 1886 Mantegazza proposed the creation of frozen sperm banks, and in 1887 Dickinson performed the first artificial insemination with donor's semen.

However, experiences in the field of in vitro fertilization in human beings began in the 20th century. In 1961 Petrucci, from the University of Bologna, developed embryos within a period of sixty days. In 1972 Pierre Soupar in the University of Vanderbilt fertilized an in vitro human ovule, which generated heated reactions. Finally, in England on July 25, 1978 doctor Patrick Steptoe and embryologist Robert Edwards achieved Louise Brown's birth, known as the first "test tube baby", an event that caused stupor, since experiments on animals had never been performed before. This fact marked a new way in human extracorporeal fertilization.

In 1984, in Canada, children's births of biological mothers different from carrying mothers were achieved. In 1985, in Australia, the case of a woman artificially inseminated with frozen semen from his dead husband occurred, thus being the first case of a birth whose embryo had been previously frozen. Also, at that time, the first cases of womb-leasing took place.

In Argentina, the assisted-fertilization method was put into practice in 1986 and in that year the first birth of twins, Elian and Paul Delaporte, occurred with the intervention of doctor Roberto Nicholson's medical team.

These new practices generated the most heated reactions and scandals, though they marked a new course without return in scientific investigations, not without recognizing the deep questions they involve in the field of Bioethics. In spite 
of it, in 1984, three children were estimated to be born per day by means of these techniques.

Although from this review the inventions achieved in the scientific and technological field arose, it is imperative that Law channels human behavior through such experiences in order to keep them within the ethical and lawful field, thus avoiding deviations that will turn them into practices incompatible with natural right that threaten against the survival of human species.

\section{The Nasciturus in Roman Sources}

Let us see which rules are found in Roman sources that could serve as a guide in spite of time distance. Taking into account that the present work is a continuity of previous investigations whose recurrent topic is the "person to be born" we will avoid repeating texts of the sources that were already object of analysis [6].

In Rome, from immemorial times, paternity presumptions: pater est quem nuptiae demonstrant (the father is the one who shows the nuptials) and maternity presumptions: maxim mater est quam gestation demonstrat (the mother is the one who demonstrates gestation) generated certainty based on an exclusivity principle; they have been currently displaced by presumptions derived from practices that only create uncertainty. In Rome, the natural way by which you entered under the pater's legal authority and, therefore, acquired the family's member condition for Roman citizens was the birth derived from the iustae nuptiae (lawful marriage), and thus Gaius says in the Iinstitutas (Institutes).

Gayo libro I. Institutionum. Item in potestate nostrasunt liberi nostri quos ex iustis nuptiis procreaverimus; quod ius proprium civium Romanorum est (Dig. 1, 6, 3) [7].

Gaius, I book. Our children, who would have been procreated from a lawful marriage and whose right is proper to Roman citizens, are also under our legal authority.

The main effects derived from that iustum matrimonium respect of the children were the relationships of paternity and filiation that generated a link between the procreated person and his/her progenitor from whom certain juridical consequences come such as the granting of rights inherent to paternity, the asking for food, the fact of being represented in judgment, the fact of being an inheritor, etc ${ }^{\mathrm{a}}$. [8]

The truth is that Romans did not hesitate about maternity, even when it was about a question of natural or illegitimate children. Maternity determination was verified by itself and it was confirmed at the very moment of the child's birth, since mother was always true, hence the principle laid down by Paulo "mater semper certa est". And we say it was, because now with assisted-fertilization techniques introduced and

a Marco Aurelio created records of marital status, ordering that every father had to declare within thirty days the birth of his children before the praefectia erarii Saturni in Rome and before the tabularii publici in the provinces. This institution is also mentioned in Apuleyo, Apology, p. 92. But the sources do not mention them, since in texts in which the phrase is found "[...] declarte ad acta" has a more generic meaning, referring not only to declarations of births but to any kind of declarations. legalized by means of law 26862 of "Medically assisted reproduction ", this principle becomes distorted.

Maternity was unquestionable as it arises from a Paulo's text in the Digest.

[...] Sed et si vulgo quaesitus sit filius, matrem in ius non vocabit (Dig. 2, 4, 4, 3) [9].

[...] Although he/she is illegitimate, the child will not summon his/her mother to trial, [...].

Paulus Iibro IV ad edictum. [...] quia semper certa est, etiamsi vulgo conceperit; pater vero is est, quem nuptiae demonstrant (Dig. 2, 4, 5) [10].

Paulo; Comments to the Edict, book IV. - [...] because mother is always true, even though her child had been conceived illegitimately; but father is the one who demonstrates the nuptials.

On the other hand, paternity determination could not be verified by itself but proved by marriage, and to give certainty to the moment of procreation within marriage, Roman legislation, from early times, established legal presumptions. From the beginnings of written law on the XII Tables, (IV, 4), there existed a provision that stated in ten months the longest gestation period and rejected the legitimacy of the child born in the eleventh month ${ }^{\mathrm{b}}$ [11]. In this regard, Paulo says in the Digest that every child born between the beginning of the seventh month after marriage celebration and the end of the tenth month after its dissolution, was legitimate and the husband was presumed to be the father of the child.

Septimo mense nasci perfectum partum, iam receptum est propter auctoritatem doctussimi viri Hippocratis; et ideo credendum est, eum, qui ex iustis nuptiis septimo mensse natus est iustum filium esse (Dig. 1, 5, 12) [12].

It has already been received due to the authority of the most learned man Hippocrates, that to be born in the seventh month is a perfect delivery; and for that reason, it is necessary to believe that the one who was born in the seventh monthfrom legitimate nuptials is a legitimate child.

This presumption of legitimacy of the child with respect to his/her father was a complete proof of the recognition of the existence of the nasciturus ${ }^{c}$ [13]. Such recognition arises from the interpretation of the abundant amount of fragments of Roman sources. One of its first manifestations occurs with the creation of the curator ventris to administer everything inherent to the nasciturus beyond patrimony.

Modestinus libro VII Differentiarum.-Ventri tutor a magistratibus populi Romani dari non potest, curator potest, nam de curatore constituendo Edicto comprehensum est (Dig. 26, 5, 20, pr) [14].

Modestino; Differences, book VII. - Magistrates of the

b In the matter Aulo Gelio in Noct. Átticas (III, 16) comments that Emperor Adriano declared a child born in the eleventh month legitimate some months after the death of the husband of a femina bonis atque honesties moribus, ambigua pudicitia.

c In spite of the synonymy used in both words, in some texts of Corpus Iuris Civilis, we prefer to use this term due to the difference marked by Suetonio inasmuch the term conceptus refers to the conception, the offspring, the fetus and the term nasciturus to the person to be born. 
Roman people should not give a Tutor to the one who is in his/her mother's womb, but he/she can be given a Curator, because in the Edict the Curator's appointment was included.

Ulpian in comments to the Edict gives entity to the nasciturus in the Digest:

Non est ambigendum, quod plerumque et contra fiscum, et contra Rempublicam admitti debeant quidam, utputa venter, item furiosus, item is, qui captivi bonorum possessionem petit (Dig. 37, 1, 12) [15].

There is no doubt that many times some must be admitted even against the Internal Revenue Service and against the republic, for example, the womb, and also the mad one and the one who asks for possession of the goods of a captive one.

Recognition of the nasciturus rarely turns out to be so clear as in the text of Gaius in Digest 37, 9, 5, pr referred to the food that the curator ventris must establish for the woman, although she has a dowry to support herself.

Gaius, libro XIV, ad Edictum provinciale. Curator ventris alimenta mulieri statuere debet, nec ad rem pertinet, an dotem habeat, unde sustentare se possit, quia videntur, quae ita praestantur, ipsi praestari, qui in utero est (Dig. 37, 9, 5, pr) [16].

Gaius, comments on the provincial Edict, XIV book. The Curator of the one who is in his/her mother's cloister must set the food for the woman, and it is not significant that she has a dowry to support herself, because it is considered that food that is given in this case, is given to the one that is in the maternal cloister, that is, the unborn child.

Although from the times of the Early Roman Empire and due to the influence of Christianity, the paternity of children born within the marriage was automatically attributed to the husband of the child's mother by application of the formula stated by Paulo; the Corpus also instituted such a presumption of legitimacy of the child with respect to his/her father as an iuris tantum presumption since the husband could destroy it by justifying the material impossibility to live together with his wife or his physical impossibility for carnal union, in accordance with the Digest in 1, 6, 6 .

Idem libro IX ad Sabinum.-Filium eum definimos, qui ex viro et uxore eius nacitur. Sed si fingamus abfuisse maritum, verbi gratia perb decennium, reversum anniculuminvenisse in domo sua, placet nobis Iuliani sententia, hunc non esse mariti filium. [...] Sed mihi videtur, quod et Scaevola probat, si constet maritum aliquamdiu cum uxore non concubiesse infirmitate intervenirte vel alia causa, vel si ea valetudine paterfamilias fiut, ut generare non possit, hunc, qui in domo natus est, licet vicinis scientibus, filium non esse (Dig. 1, 6, 6) [17].

Idem; comments to Sabino, IX book. We define a childs the one that is born from a husband and his wife. But if we knew that the husband was absent, e.g. for ten years, and after his return he found a one-year-old child in his house, we are in favor of Juliano's opinion that this child is not a child of her husband. [...] But it seems to me and Scaévola also approves it, that if the husband did not lie for some time with his wife owing to disease or to another reason, or that if the father of the family had such a disease that he could not engender a child, the one that was born in his house, although his neighbors know it, is not his child.

As legal presumption admitted evidence to the contrary, the husband could ignore the paternity of a child, even though he/she had been born in the stipulated time according to the knowledge of Hippocrates. In this respect, the transcribed text is categorical. In such an assumption, the praetorian right to assure the condition and the rights of the child granted his/her mother a prejudicial action of recognition, the actio of partu agnoscendo by means of which the Plaucian Senatum Consultum, from Vespasian's time, in its second part, ordered the pregnant divorced woman to notify her husband of such a condition within thirty days following the divorce, so that she could control the course of pregnancy under the penalty of taking paternity for granted, Paulo says in his Sentences:

Si mulier diuortio facto grauidam se sciat, intra tricensimum diem uiro denuntiare debet uel patri eius, ut ad uentrem inspiciendum obseruandumque custodes mittant: quo omisso partum mulieris omnimodo coguntur agnoscere (P. S. XXIV, 5) [18].

If a woman, after divorce, knows that she is pregnant, she must notify her husband or his husband's father within thirty days in order that they send guardians to examine and observe her womb; notifications being omitted, they are forced to wholly recognize the woman's new born child.

In this way, the husband's right to have the woman's womb examined by midwives was established - it seemed that by an imperial provision due to the use of the expression placuit. For the purpose of proving pregnancy certainty in classical law the way adopted in practice was that of calling iudexan expert in the matter, so that he was a judge and an expert simultaneously. Those who fulfilled this role were midwives in status and succession actions. And for the case in which these replaced fraudulently a newborn child (partus suppositus) the maximum penalty was established for them.

IP Si quaecumque mulier matrimonio per diuortium disoluto praegnantem se esse senserit et hoc in notitiam mariti ue lpatris eius detulerit, ut ad inspiciendum uel obseruandum uentrem suum custodes mittant, quos dum miserint, partum mulieris, id est natiuitatem sui heredis, compelluntur agnoscere. (PS XXIV, IP)

Si mulier se ex uiro praegnantem neget, permittitur marito uentrem inspicere et uentri custodes dare. (P. S. XXIV, 7)

Venter inspicitur per quinque obstetrices, et quod maxima pars earum denuntiauerit, pro uero habetur. (P. S. XXIV, 8)

Obstetricem, quae partum alienum attulit, ut supponi possit, summo supplicio adfici placuit. (P. S. XXIV, 9)

Necare uidetur non tantum is qui partum praefocat, sed et is qui abiicit et qui alimonia denegat et is qui publicis locis misericordiae causa exponit, quam ipse non habet (P. S. $X X I V, 10)$ [19].

IP - If any woman, her marriage being dissolved by divorce, realized that she is pregnant and made this known to her husband or to his husband's father so that guardians would be sent to examine or observe her womb, while they 
send them, they are forced to recognize the woman's newborn child, i.e, the birth of their inheritor.

If a woman denies being pregnant with her husband, he is allowed to examine her womb and to provide guardians for it.

Her womb is examined by five midwives and what the majority of them has notified is regarded as true.

It was considered good that the midwife who takes a newborn child belonging to others in order to be able to replace him/her, shall be punished with death penalty.

It is understood that not only the one who drowns the newborn child kills, but also the one who abandons him/her, the one who denies food to him/her and the one who exposes $\mathrm{him} /$ her in public places because of a mercy that he himself does not possess.

The latter text that is also in Digest 25, 3, 4, applies to anyone who threatens against the newborn child's life, be the midwife, his/her mother, his/her father or any other. Notice that death is ranked equally with abandonment or exposure in public places. We understand that these grounds might be applied by analogy to those that are currently born by assisted-fertilization procedures and abandoned or exposed in fertilization banks. And food denial might be compared to hydration and food withdrawal allowed in the wrongly called law of dignified death.

A Senatum consultum in Adriano's times extended these provisions to the case of marriage dissolution due to the husband's death, in which case his spouse had to communicate her pregnancy to her husband's pater familias under the legal authority of whom the child who would have to be born had to fall. Otherwise, she lost the right to try the action de partuagnoscendo. Ulpiano says in the Digest:

Quia Plaucianum Senatusconsultum ad eos partus pertinet, qui post divortium eduntur, aliud Senatusconsultum temporibus Divi Hadriani factum est, utetiam si constant matrimonio partus sit editus, de adnoscendo eo agatur (Dig. $25,3,3,1][20]$.

As the PlaucianSenatum Consultum refers to childbirths that are delivered after divorce, in Divine Adriano's times another Senatum Consultum was promulgated so that if the childbirth had been delivered during marriage, you should proceed as regards its recognition.

In this assumption, title IV of book XXV of the Digest "about the inspection of her womb and the custody of the childbirth " (de inspiciendo ventre) regulates in detail all the precautions that had to be taken for the case of the childbirth after his/her father's death. In such a case, midwives fulfilled a transcendent role for the purpose of certifying the childbirth's product and of assuring the paternity of such a child to be assigned to the previously dead husband.

[...] Si mulier mortuo marito praegnantem se essedicet, his, ad quos ea res pertinebit, procuratorive forum bis in mense denutiandum curet, ut mittant, si velint, quae ventrem inspicient. Mittantur autem mulieres liberae dumtaxat quinque, haeque simul omnes inspiciant, dum ne qua earum dum inspicit, invita muliere ventrem tangat. [...]. Mulier ante dies triginta, quam parituram se putat, denuntiet his, ab quos ea res pertinet, procuratoribus ve eorum, ut mittant, si velint, qui ventrem custodiant. In quo conclavi mulier paritura erit, ibi ne plures aditussint, quam unus; si erunt, ex utraque parte tabulis praefigantur. Ante hostiumeius conclavis liberi tres, et tres liberae cum binis comitubus custodiant. Quotienscumque ea mulier in id conclave aliuve quod, sive in balineum ibitcustodes, si volent, id ante prospiciant, et eos, qui introierint, escutiant; [...]. Mulier, cum parturire incipiat, his, ad quos ea res pertinet, procuratoribusve eorum denuntiet, ut mittant, quibus praesentibus pariat. Mittantur mulieres liberae dumtaxat quique, ita ut praeter obstetrices duas in eo conclavi ne plures mulieres liberae sint, quam decem, ancilae, quamsex. Hae quae intus futurae erunt, excutiantur omnes in eo conclavi, ne qua praegnans sit. Tria lumina, ne minus ibi sint, scilicet quia tenebrae ad subiiciendumaptioressunt. Quod natumerit, his, ad quos e ares pertinet, procuratoribusve eorum, si inspicere volent, ostendatur [...] (Dig. 25, 4, 10) [21].

[...] If, once her husband was dead, the woman would say she is pregnant, beware of letting those who are interested in the person or the prosecutor be known twice a month in order that they will send, if they want to, those who will inspect her womb. Even more, send only five free women, and inspect it in all of them at the same time, provided that none of them touches the womb against the woman's will, while he inspects it. [...] Thirty days before the woman feels she will have to give birth, make it known to those who are interested in the person or to their prosecutors, so that they will send, if they want to, those who will guard her womb. The room in which the woman has to give birth should have only one entry; and if there were more, nail them with tables on both sides. Let three free men and three free women stand on guard in front of the door of that room with two companions. Providing that the woman will go to that room or to any other one, or to that of the bathroom, examine them before the guards, if they want to, and register those who enter it; $[\ldots]$. When the woman begins to give birth, let it be known to whom are interested in the person, or to their prosecutors so that they will send persons in whose presence the birth will occur. Send only five free women so that besides two midwives in that room there will be no more free women than ten, or more slaves than six. Be all the women in the room registered because someone might be pregnant. Be there three lights and not less, namely, because darkness is more on purpose for the assumption of a birth. Show who was born to those who are interested in the person or to their prosecutors, if they wanted to inspect it. [...].

Such precautions were considered to be indispensable, even more for the assumption that the woman would get married again before the established prohibition period. In this respect, August Emperors Graciano, Valentinian and Theodosius said addressing Eurtropius, Prefect of the Praetorium:

Iidem AAA. Eutropio P. P.- Si qua ex feminis perdito marito intra anni spatium alteri festinaverit nubere parvum enim temporis post decem menses servandum adiicimus, tametsi id ipsum exiguum putemus, probrosis inusta notis, 
honestioris novilisque personae et decore et iure privetur, atque omnia, quae de prioris mariti bonis vel iure sponsalium vel indicio defunct coniungis consecuta uerat, amittat. [...] (Cod. 5, 9, 2) [22].

The same Augusts to Eutropius, Prefect of the Praetorium. If any woman, having lost her husband, had hastened to get married with another one within the term of one year, (because we add that a brief period will have to be observed after ten months, although we consider it to be very short), accused with insulting notes, be deprived of consideration and of the right of honest and noble person, an lose everything of the goods of what she had obtained from her first husband by the right of betrothal or by the last will of the late spouse. $[\ldots]$.

The custody of the childbirth was granted even though it was a question of a slave in order to prevent the assumption of births.

Sed et si servis heres institus fuerit, si nemo natus sit, Aristoscribit, hic quoque servuo, quamvis non omnia, quaedam tamen circa Jartum custodiendum arbitrio Praetoris ese concedenda [...] (Dig. 25, 4, 1, 13) [23].

But also if a slave had been instituted an inheritor, if nobody had been born, Ariston writes that likewise in this case the slave should be granted, at the discretion of the Praetor, although not all, some, however, with regard to the custody of the childbirth. [...]

As well as the mother could begin an action of recognition by virtue of the Plaucian Senatum Consultum, the child could also demand the recognition of paternity, even if his/her father had died, by means of the actio de liberisagnoscendo that only had the scope of imposing on the father the obligation of supplying food, but it did not recognize the plaintiff child the rights inherent to paternity, or prevent his/her grandfather from denying him/her later the quality of a family.

In the same protective direction of the person to be born in succession matters, the edict of the praetor regulated the measures the pregnant widow had to take with respect to the persons who would intend to be inheritors of her previously dead husband and granted her the right to obtain, in favor of the child to be born, a provisional possession of the deceased's goods, by means of the bonorum possession ventrisnomine instead of giving him/her the possession of the goods against testament.

Ulpianus libro XVI ad Edictum. Sicuti liberorum forum, qui iam in rebus humanis sunt curam Praetor habuit, ita etiam eos, qui nondum nati sint, propter spem nascendi non neglexit; nam et hac parte Edicti eos tuitus est, dum ventrem mittit in possessionem vice contra tabulas bonorum possessionis (Dig. 37, 9, 1, pr.) [24].

Ulpian; Comments to the Edict, book XVI. - As well as the Praetor took care of the descendants that had been born, he did not either neglect, for the hope that they were born, those who had not yet been born, because he also protected them in this part of the Edict, putting the one that is in his/her mother's womb in possession instead of giving him/her the possession of property against the will.
In the case that the child of the previously dead husband were prepubescent and other testamentary inheritors or ab intestate would deny him/her the status of inheritor and dispute the inheritance, the praetor Carbon, previous to Hadrian, granted him/her by the Edict called Carbonian, the (bonorum possession ex edicto Carboniano) up to the age of puberty.

Ulpianus libro XLI, ad Edictum.-Si cui controversia fiet, an inter liberos, sit, et impubes sit, causa cognita perinde possession datur, ac sinulla de ea re controversia esset, et iudicium in tempus pubertatis causa cognita differtur (Dig. $37,10,1)$ [25].

Ulpian: Comments to the Edict, book XLI. If anyone promotes controversy on himself/herself on the number of descendants, and were pre-pubescent, he/she will be given possession with knowledge of the facts, the same as if there had not been any controversy on this point, and judgment would be postponed by knowledge of the facts for the time of puberty.

And the praetor matched the protection of the prepubescent with that of the nasciturus in the matter of Carbonian possession of property and considered the possession for the latter more justified, not only by the family's right, but even more by the Republic's right.

Et generaliter, ex quipus causis Carbonianam bonorum possessionem puero Praetor dare solitus est, ex iisdem causis ventri quoque subneniere Praetorem debere non dubitamus, eo facilius, quod favorabilior est causa partus, quampueri; partui enim in hoc favetur, ut in lucem producatur, puero, ut in familiam inducatur; partus enim iste alendus est, qui et si non tantum parenti, cuius esse dicitur, verum etiam Reipublicae nascitur (Dig. 37, 9, 1, 15) [26].

And, in general, we do not doubt that for the same causes the Praetor used to give the pre-pubescent the Carbonian possession of property, he must help the one who is in his/her mother's womb, even more when the reason of the fetus is worthier than that of the pre-pubescent; because the fetus is favored for this, to be born and the pre-pubescent to be introduced in the family, since this fetus would be fed, who is born not only for his/her father, of whom he/she is said to be, but also for the Republic.

In testamentary matters, in what is related to disinheritance, what was inherent to the nasciturus was also regulated, so that no doubts will be left behind.

Nominatem autem exheredatus postumus videtur, sive ita dixerit: "quicunque mihi nasceretur", sive ita: "ex Seia", sive ita: "venter exheres esto"; sed et si dixerit: "postumus ex heres esto", natus vel post mortem, vel vivo testatore non rumpet (Dig. 28, 3, 3, 5) [27].

However, the posthumous was considered to be nominally disinherited if the testator had said in this way anyone that will be born from me, or in this way: "of Seya", or in this way: "the one that is in the womb will be disinherited"; but also if he had said: "The posthumous will be disinherited"; the one that was born or after death, or if the testator lives, will not break the testament.

The transcribed texts, selected from many others from the 
sources, evidence that both legislation and the Roman juridical conscience conceived the person to be born as a human being independent from his/her mother and worthy of the most effective legal protection. From the texts cited by the sources, you can notice the keenness exhibited by the Romans from earlier times to protect life from the very moment of conception, to give paternity the major certainty, to avoid the substitution of the born child, to put property under custody that due to succession could correspond to the conceived person, even in the case of a slave. They protected especially the right to the conceived person's identity (with the inspection of the womb and custody of the childbirth), but they were not careless of the patrimonial aspect. Midwives' mission was meticulously ruled in defense of the conceived person's identity taking all precautions, as it arises from title XXV, chapter IV paragraph 10 of the transcribed Digest. The preservation of the person to be born was inherent to public interest which meant, for the Republic, the birth of a new human being.

Today these circumstances have been overcome by the DNA test, but partially because such a method will not turn out to be satisfactory when errors or fraud in the embryos' identity occur; at best the custody chain protocol will allow to identify the person in charge ${ }^{\mathrm{d}}$.

The Romans devised a tuition legislation for the conceived person in the mother's womb that they left no aspect without covering. Surely, its pragmatism evidenced in such a detailed regulation embodied in the Corpus Iuris Civilis for the conceived person in his/her mother's womb would not have allowed the enactment of laws which, without solution of continuity, threatens against life and questions the true identity of the conceived person. Here is the question, in the procedures legalized by law 26862, who will fulfill the role that Roman matrons performed so well in order to assure the legitimate union of gametes, their transfer to the woman's uterus, the implantation of the embryo in the woman's womb, the identity of embryos lying in fertilization banks, the paternity and the maternity of those children?

According to the circumstances of the social and economic organization, there was more secrecy to determine paternity by taking into account the incipient or void development of science. As inferred from transcribed texts, evidence was equally rudimentary and, as a consequence, it became logical that Romans had only found maternity unlike paternity as absolutely accurate, prevailing in any case that the childbirth event was the suitable test to determine maternity. It is, then, that Roman jurisconsults faithful to their pragmatic and realistic style focused on the incontrovertible and empirical

d The DNA test completely supports the identity of the conceived person, and as this one develops, the possibility of distinguishing unequivocally the origin of a sample even when the potential donors are monozygote twins is increasing, due to the differential accumulation of mutations. But no technique in which the human being intervenes is guaranteed against error or fraud, but if it guarantees that if they occur, they will be discovered. It also has its limitations since for that to investigate the individual under study and/or his/her supposed progenitors will be needed and, by using the markers suitable in quality and quantity, a certainty of $100 \%$ in the exclusions will be able to be reached, but of $99,99 \%$ in the inclusions. biological birth event. But not without admitting that the nasciturus really exists and as such he/she enjoys the benefits he/she can receive, hence the rule enunciated by Gaius "the conceived person is considered to be already born" expresses reality in the sources, leaving behind the principle that formulates that the person of physical existence begins with "birth" and, replacing it for that of "conception". Among modern writers who also share the same doctrine, is the outstanding Italian Romanist Pierángelo Catalano who rejects the theory of fiction by holding that it has no Latin origin but that it is the creation of postsavignian pandectistics and postulates the ontological equivalence between the conceived person and that of the already born, which is found in book I title $\mathrm{V}$ (De status hominum) which is analogous to book L title XVI (De verborum singnificatione) [28].

\section{The Ontological Statute of the Extrauterine Embryo. Grounds for Juridical Regulation}

Fertilization is a continuous process that occurs from the very moment the sperm cell head enters the ovule cytoplasm to the fusion of the two pronuclei of parents' gametes, which form the zygote, a new biological entity that is not either that of the father or that of the mother but that of a new being who develops by himself/herself. From that very moment the embryo which has a unique genetic component, is exactly the same as the one that is going to come to life later; therefore, it is a question of an "another one", a real and not a potential person. And both for civil and penal legal protection, the degree of the embryo evolution does not matter whether the ovum has just been fertilized or takes several weeks or months of evolution, not even the place in which it has been fertilized because the inalienable value of a human being goes beyond his/her development. The same position as regards the nature of the embryo is the one that Roman sources indirectly recognized because although to the naciturus created in his/her mother's womb was not granted legal personality but after his/her birth, Roman legislation recognized him/her as such on designating to him/her the curator ventris to guard over his/her succession rights, on determining his/her character of legitimate child or free or citizen when his/her mother had lost, between both moments, freedom or citizenship or to execute death penalty on his/her mother. In the matter, the outstanding Italian Romanist Pierangelo Catalano holds that "[...] this proof of modernity comes to confirm that the nasciturus (in vitro or in vivo) does not turn out to be a viscera or a part of his/her mother's organism, a portio mulieri vel viscerum as a Germanizedbased interpretative current - read Savigny -, but we are in the presence of a current human being qui in uterus est as the Roman - Iberian conceptualization of naturalistic base affirmed from which Freitas and Vélez Sársfield nurtured" [29]. Without going deep into the description and technical considerations of the different processes of assisted fertilization since they go beyond the purpose of this work, it 
is necessary to clarify that none of them guarantees the dignity of the human person's procreation, since none of them refers to the "formation of the first cell" as the initial milestone of human development. For this reason, the term "conception" - intentionally turned into ambiguous - or "fertilization" - which does not cover the whole current ways according to which a human being might begin to exist, is used. In all of them, the embryo initiates its life out of the mother's uterus under conditions that put its integrity and its very survival in danger; it is the ground for obtaining a repressive legislation for those who practice them because they inexorably lead to the direct or indirect destruction of embryos, such as the discard of non-implanted embryos, cryopreservation, straightforward defrost, the use of gametes from third parties, the resuscitation of defrosted embryos, the use of embryos under experimentation. Respect for life from the very moment of conception became strengthened by the jurisprudence of national and international courts. In various decision courts, the beginning of human life was supported to begin in the conception and, therefore, from this moment a person with rights comes into existence.

In Argentina, one of the first pronouncements on the persons' juridical nature conceived out of the mother's womb and on the protection of supernumerary embryos, was that of the National Chamber of Civil Appeals of the Federal Capital. In December, 1999 in the proceedings Rabinovich, Ricardo on/protection that were processed before the National Civil Court of First Instance $\mathrm{N}^{\circ} 56$, it was provided: $[\ldots]$ a) to carry out a census of non-implanted embryos and proceed to their individualization, b) to prohibit any action on them that will imply their destruction or experimentation; c) to order that any material or juridical provision of them $[\ldots]$ will be materialized by judicial intervention and by the Prosecutor's General Office [...] [30].

In May, 2011 Room IV of Chamber of Civil and Commercial Appeals in Corrientes revoked the judgment of first instance in the Proceedings " L. A. C. (Law of Account Audit) against/the Health Insurance System of the Union of the Civilian Personnel of the Nation on/protection " that condemned the Health Insurance System of the Civilian Personnel of the Nation to cover an affiliate and his/her spouse regarding the whole expenses, costs and other expenditures that would require a treatment of assisted fertilization $^{\mathrm{e}}[31]$.

The application of the FIVET (In Vitro Fertilization with Embryo Transfer) technique has also received judicial sentence in a valuable judgment of the Supreme Court of Costa Rica on March 15, 2000, which considered that assisted fertilization techniques threaten against human $\operatorname{life}^{\mathrm{f}}$ [32].

e In the most relevant part of the court decision the Chamber said: "the duty of life protection as a constitutional right prevents the State to assume abortive policies, promote genetic manipulation, impose controls of birthrate, etc. [...] neither the cloning nor the destruction of embryos, nor the interruption of pregnancy admit to be located between self-referent behaviors though it is not because the life of others is involved".

f On this matter the court affirmed: "[...] during the carrying out of the FIVET technique, the embryos previously fertilized in laboratory are transferred to the
As far as it is concerned, the European Court of Justice based in Luxembourg declared itself in favor of the defense of human life. In the case 34/10 "Oliver Brüstle vs. Greenpeace e. V." on October 19, 2011 it recognized the human embryos entity from the single-celled beginning of its existence, whatever the modality of its genesis and independently of its viability, which constitutes a valuable contribution in support of biology, covering all the possible results, and against the aberrations that technology can allow ${ }^{\mathrm{g}}$ [33].

More recently, the Constitutional Spanish Court, on June 25, 2015 declared in plenary session in defense of the embryo in the case of pharmacist "Joaquín Herrera Dávila on/supply of the morning-after pill", because the antiimplantation effect of the drug has been demonstrated scientifically by the levonorgestrel active ingredient and, therefore, due to the recognition of the right to the pharmacist's objection of conscience, thus rescinding the penalty that the Meeting of Andalusia imposed on him for not having dispensed it $^{\mathrm{h}}$ [34].

The fact that national, foreign and international judicial pronouncements defend life so much from the very moment of the conception grants legal entity to the embryo and considers that AFT (assisted-fertilization technique) threatens against human life.

\section{Current State of the Issue in Argentine Law}

The Argentine Civil Code in force until a few days ago had established without hesitation the beginning of the person's existence at the very moment of conception, a position sustained for a period of forty-six years, since Vélez Sársfield wrote his masterpiece in 1869.

In Argentina, the method of assisted fertilization was applied from 1986 to 2013 without any legal regulation. Only then, a law was issued on the incomplete, ambiguous matter and with devastating effects, because although the killing of embryos was already a reality in our country, they had never enjoyed legal protection or state financial coverage, acts being now legalized by law 26862/2013 leading to distort social conscience and to enhance the covert genocide that entails the death of invisible but real beings.

uterus knowing most of them is destined not to generate a pregnancy. [...] The essential point is that embryos whose life is sought first and then frustrated are human beings and the constitutional ordering does not admit any distinction among them. [...]. la application of the in vitro fertilization technique and embryonic transfer, in the way in which it develops today, threatens against the human life".

g The judgment of the Tribunal of the European Union (TUE) indicates that every fertilized human ovum from fertilization should be considered a "human embryo". The judgment declares that "[...] a biotechnological invention should be excluded from the juridical protection of patents when it has required, for its process, the previous destruction of human embryos or uses them as base material".

$\mathrm{h}$ The Supreme Court supported: "[...] the sanction violated the right to the objection of conscience as a manifestation of the ideological and religious freedom the Constitution recognizes in its artículo16.1. [...] the most recent scientific evidence suggests that the post-coital pill, can act not only preventing ovulation, but also making the implantation of the embryo difficult $[\ldots] "$. 
The doctrine was accepting peacefully that by analogy the beginning of existence in the conception was applied to the cases in which fertilization had been conducted out of the mother's womb [35].

By virtue of such analogy, the embryo conceived by means of assisted-procreation techniques, even before being implanted in the mother's womb, was considered to be a person to be born. The project of the Civil Code of 1998 supported the above-mentioned criterion by eliminating the expression "in the mother's womb".

But the editors of the reform project of 2012, ignoring the research advances in medicine and biology, did not know the character of being human to the embryo formed out of the mother's womb, in the period previous to implantation, according to the original wording of the projected article 19. After heated debates, the paragraph of art. 19 of the original project that fixed the beginning of the existence of the conceived person out of the mother's womb at the moment of implantation was removed. But the paragraph suppressed from the approved text remains in force tacitly by virtue of what was established in articles 560 and 561 of the same juridical digest that allows the person who submits to the use of human-assisted reproduction techniques to retract from the consent given until the moment of the embryo implantation. In the same sense, art. 7 of law 26862/2013 was written.

This leaves countless questions without answers: what to do with the supernumerary embryos that already exist in fertilization banks and with those that continue to be generated? Let them die? To give them up in adoption? To provide the cessation of cryopreservation? What to do in case of divorce, parents' separation or death? Among many other questions, which generate new ethical and legal scenarios. In the foundations of the project severe omissions were justified in the so called "self-referential behaviors" in article 19 of the National Constitution. Such an interpretation contains a malicious intentionality any time you cannot turn those omissions into a protective umbrella to cover any trial that occurs to doctors, investigators and parents, because the others' life is at stake as the Chamber of Appeals argued in Corrientes in 2011.

From the constitutional reform of 1994, the right to life is an explicit right by the incorporation of the international treaties enumerated in art. 75 subsection 22 and those which joined later. In that sense the American Convention of Human Rights protects life from the conception (art. 4 subsection 1) without any distinction about the place where it occurs. In identical sense, the Convention on the Laws of the Child repeated in the preamble what it already supported in the Declaration of the Laws of the Child (art. 1) a child is every human being under eighteen, our country making the exception on ratifying it by means of Law 23849 (art. 2) that article 1 should be interpreted in the sense of what is understood by a child "every human being from the moment of conception up to the age of eighteen", without having formulated any distinction. Pursuant to the Convention of the Laws of the Child, he/she has the right to have the right to life guaranteed (art. 6), to preserve his/her identity (art. 8), his/her survival and development, to know his/her parents and to be taken care by them (art. 7). By the application of this agreement, no law can authorize the discard of embryos (right to life), the selection of embryos (right not to be discriminated), the fertilization with gametes of third parties outside marriage (right to identity and to know his/her parents), the access to assisted fertilization represented by single or alone women (right to have a family). Later, law $26061 / 2005$ of integral Protection of the rights of girls, boys and teenagers in its art. 2 declared such Convention of compulsory application.

All that is precisely what has been legalized with the enactment of law 26862/2013 that ignored that life begins with the conception, and included the donation of gametes or embryos (art. 2), the adoption by homosexuals (art. 8), the cryopreservation of gametes or of reproductive tissue (art. 8), in an open violation to this agreement. Neither this law nor its regulatory decree includes among its provisions some precautions destined to the prevention of endogamy. In this matter, the Civil Code in art. 564 allow to reveal the donor's identity by means of judicial intervention, which might turn into a requirement of very difficult application to prevent endogamy.

What was briefly pointed out turns out to be incompatible with the right to identity embodied in the Convention that Argentina ratified.

That evidences a claudicating State in defense of innocent life and in its character of sovereign, because it has yielded to the pressures and interests of international organizations that promotes and finance and through which these policies that threaten against health and life are canalized.

"The child to be born is not only a person with respect of his/her mother, but also, and fundamentally, he is a son/she is a daughter and this condition for his/her parents includes rights but also duties that the State must guarantee [...] Nobody can validly consent the killing of a human being, not even his/her mother, who cannot decide on a life that does not belong to her, not even when she finds herself in conflict with her own" [36].

\section{Conclusions}

In spite of the positions in favor of assisted reproduction techniques, we estimate that either national or international legislation should absolutely forbid the development of any form of extracorporeal fertilization and its direct and immediate consequence, the cryopreservation of embryos and establish the corresponding punishment for the offender. Only in this way the respect for the embryo's life and the human species' survival under conditions of equality with the one that allows to discern the other individuals of the human species will be guaranteed. But as the national and international trend proves to be favorable to it, concealing the true pursued purpose, to try to persuade with this position is not easy.

However, since you cannot ignore the countless cryopreserved embryos in fertilization banks exposed to an 
absurd luck, without lawfully pursuable safe survival ways and exposed to death risks or to irreversible damages in their physical integrity, some solution should be looked for them through legislation. This should have as pillars: a) the primordial right of the embryo - to be born - considering it a person from the very moment of conception b) his/her development in a familiar environment constituted by the known and safe reference of his/her parents, so that they could discover his/her own identity and reach his/her maturity, c) the maximum protection for the already existing embryos by demanding medical doctors to transfer them at once to the owner of the gametes' uterus or to another one to guarantee their survival, d) the classification of forbidden practices and their punishment. But this will not be a reality while legal rules - some of them analyzed in this work - that allow the development of unlimited assisted-reproduction techniques are not re-formulated in order to guarantee prevailing equality in art. 16 of the National Constitution and according to international treaties with constitutional hierarchy that defend life from the very moment of conception [37].

For that reason, we recall the court decision that ordered to do a census of cryopreserved embryos in the city of Buenos Aires. In that process a tutor was appointed to fulfill what was ordered in the court decision which, far from being materialized, was frustrated. We estimate that failure was due to the appointment of an individual as tutor without assigning him any state infrastructure (not either material or economic human resources). In the facts the figure of the tutor did not persuade with sufficient force to have the court decision accepted, so the consequences are obvious [38].

We estimate that, by taking as a guiding thread that court decision which was very plausible in its intentionality but frustrated in its enforceability, Roman law can serve as a guide to diagram a juridical figure in the field of public law: The "defender of the extrauterinely conceived person" in the same way as in the republican Rome the defender civitatis was instituted to defend the low classes of the municipality (plebs) from vexations of powerful men (potentiores) and from the abuses of civil servants.

In our country, in the area of judicial organization, there exists the defender of absentees, the defender of the poor and the defender of minors, and the National Constitution of 1994 introduced the ombudsman who had already been created by law 24284/93.

Although at present it is the General Prosecutor' office which, through the Defender of Minors, in the orbit of the Judiciary, intervenes in the cases in which questions related to embryos originated by means of assisted-fertilization techniques are debated, the interested parties are forced to resort to tribunals in order to elucidate the issue, with the setbacks it implies to them. Then, most cases are solved in the private area at the mercy of the unlimited ambition of scientists that distort the information to act on the parents' ethical sensitivity, exerting a dominion on the others' destination, since they arbitrarily determine who will be allowed to live and who will be destined to death. An organism that exclusively watches over the rights of the extrauterinely conceived person would yield more favorable results in its defense. The suggested figure of the "defender of the extrauterinely conceived person" would have as a mission to represent the most defenseless of mankind, to guard over the personal and patrimonial interests of this huge quantity of human beings who debate between being or not being and simultaneously to exert police power on the custody of the existing cryopreserved embryos - until the last one will be implanted - and to control the exercise of such practices by avoiding deviations that will turn them into procedures at odds with the natural right that can put human species survival in danger. And this happens when a human being places himself/herself in the center of the scene and ends up by giving priority to his/her circumstantial convenience, and he/she turns everything else into relative.

Going back to the title of this work, we are persuaded that there is no lasting advance without strengthening in the roots, because to innovate is not to dissociate from tradition, but to join it and from there be projected beyond times, but without abandoning natural reason.

\section{References}

[1] Estrada, S., The person to be born in the Corpus Iuris Civilis, in Vélez Sársfield Code and in the Project of the Argentine Civil Code of 1998, presentation submitted in the XV Latin American Congresso of Roman Law, Michoacan, University of San Nicolás of Hidalgo and Veracruz University, Morelia, Mexico, August, 2006 published in Rome and Argentina, Dialogue of cultures. ILLAC Ed. Faculty of Philosophy and Literature, National University of Tucumán, Tucumán, 2008, ps. 151-165. Estrada, S., The protection of the nasciturus: an evolution from the Roman sources up to the present of the Argentine positive law, in Magazine New Proposal of the Catholic University of Santiago del Estero N49, IDEART Ed., Santiago del Estero, June, 2011, ps. 175-214. Estrada, S., The person to be born in the Roman sources and the irprojection to the Argentine legislation, in Magazine of the Association of Roman Law of the Argentine Republic, vol. VII, Ed. Publifadecs, Ed., General Roca, Rio Negro, Argentina, April, 2013, ps. 59-81.

[2] Jonas, Hans, Technique, medicine and ethics, Paidós, Barcelona, 1997.

[3] Cicerón, Marco Tulio, The Republic L. 4, chap. I, Aguilar Argentina S. A. de Ediciones, Buenos Aires, 1967.

[4] Zavala de González M., Abortion, person to be born and the right to life. The law 1983-D-1126.

[5] Sgreccia, Elio, Manually of Bioethics, Institute of Humanities in Health Sciences, Diana Ed. México 1996, ps. 399 and following pages.

[6] Estrada, S., op. cit.

[7] García del Corral, Ildefonso, Body of Roman Civil Law, published by brothers Kriegel, Hermann and Osenbrugger, Barcelona, 1892, v. I, p. 217.

[8] Mainz, C., Course of Roman Law, tr. A. J. Pou and Ordinas, Molima, Barcelona, 1892, v. III, p. 97. 
[9] García del Corral, Ildefonso, op. cit., v. I, p. 251.

[10] Aulo Gelio, "Noct Átticas", III, 16, Editorial Perlado, Madrid, España, 1923

[11] García del Corral, Ildefonso L op. cit. v. I, p. 214.

[12] Cayo Suetonio Tranquilo, "Lives of the Twelve Caesars" tr. F. Norberto Castilla, Librería de Perlado, Paez y Cía, Madrid, 1917.

[13] García del Corral, Ildefonso L op. cit. v. II, p. 243.

[14] Ibidem. v. III, p. 9.

[15] Ibidem v. III, p. 47.

[16] Ibidem, v. I, p. 218.

[17] Irigoyen Troconis, M. P., Paulo, J., Sentences to his son. Institute of Juridical Investigations-Institute of Philological Investigations, México, 1994, book 2v. I, p. 49.

[18] Ibidem, book 2, p. 51.

[19] García del Corral, Ildefonso, L., op. Cit., v. II, p. 215.

[20] Ibidem, v. II, p. 220.

[21] Ibidem, v. IV, p. 576.

[22] Ibidem, v. II, p. 221.

[23] Ibidem, v. III, p. 43.

[24] Ibidem v. III, p. 48.

[25] Ibidem, v. III, p. 45.

[26] Ibidem, v. II, p. 351.

[27] Catalano, Pierángelo, Law and Person, G. Giappichelli Editor, Torino, 1990. And The initiation of the person in the Roman Legal System, in Updating of Roman Law in Giorgio La Pira'sthinking, Rome: Sapienza University, 1997, p. 234.

[28] Ibidem, p. 228.

[29] Rabinovich, Ricardo, on preventive measures (R., R. D.), ED185-412. www.juscorrientes.gov.ar/novedad.php\%3F.

[30] www.juscorrientes.gov.ar/novedad.php\%3F

[31] The Law, October 30, 2001, court decision of the Constitutional Chamber, Supreme Court of Costa Rica. http: // curia.peuropa.eu/jurisp/cgi.

[32] http: // curia.peuropa.eu/jurisp/cgi.

[33] http://www.tribunalconstitutional.es/es/sala004125TC.pdf.

[34] Rivera, Julio C., Institutions of Civil Law, general part, volume I, $4{ }^{\circ}$ updated and extended edit., Lexis Nexis Abeledo Perrot ed., p. 408.

[35] Bach de Chazal, R., Abortion in Argentine Positive Law. The Law. Buenos Aires, 2009, p. 56.

[36] Conclusions in the Spanish-American Congress of Family Law, Cáceres, Spain, 1987, Año VII, N³7.

[37] Rabinovich, Ricardo, on preventing measures (R., R. D.), ED$185-412$.
[38] Andorno R., Law before the new eugenesics: selection of in vitro embryos, in bioethics notebooks No 0, Buenos Aires: Ad-Hoc, 1996.

[39] Arangio Ruiz, V., Institutions of Roman Law, tr. J. Caramés Ferro, Buenos Aires: Depalma, 1952.

[40] Arias Ramos, J., Roman Law, Madrid: Journal of Private Law, 1947.

[41] Aulo Gelio Noct Atticas: Anthology, tr. Francisco García Jurado, Madrid: Alliance Editorial, 2007.

[42] Aznar, J. T., ZENIT. Obtainedfrom ZENIT: https://es.zenit.org/articles/el-tribunal-constitucional-avala-lanegativa-a-dispensar-la-pildora-del-dia-despues/, August 7, 2016.

[43] Bach de Chazal, R., Abortion in Argentine positive law, Buenos Aires: The Law, 2009.

[44] Barra, R., Constitutional protection of the right to life, Buenos Aires: Abeledo Perrot, 1996.

[45] Basso, D., Be born and die with dignity, 3rd. Ed. extended, Buenos Aires: Desalma, 1991.

[46] Blanco, L., Some consideration about bio law in Argentina, in bioethics notebooks, year 3 No 2 .

[47] Santiago: Tórculo Graphic Art, 1998.

[48] Beluscio-Zanoni, Civil Code and complementary laws. Buenos Aires: Astrea, 1978.

[49] Catalano P., Law and person, Torino: G. Giappichelli, 1990.

[50] Catalano, P., The initiation of the person in the Roman Legal System, in Updating of Roman Law I Giorgio La Pira'sthinking, Rome: Sapienza University, 1997.

[51] Civil and Commercial Code of the Nation. 1st ed. Autonomous City of Buenos Aires: Infojus, 2014.

[52] Estrada S., The person to be born in the Corpus Iuris Civilis, in Vélez Sarsfield, Code and in the Project of the Argentine Civil Code of 1998 in Rome and Argentina, Dialogue of cultures, Tucumán: ILLAC Faculty of Philosophy and Literature, National University of Tucumán, 2008.

[53] Estrada S., The protection of the nasciturus: an evolution from the Roman sources to the present of the Argentine positive law, in the Magazine New Proposal soft the Catholic University of Santiagodel Estero No 49, Santiago del Estero: IDEART, 2011.

[54] Estrada S., The person to be born in Roman sources and the irprojection to the Argentine Legislation in the Magazine of the Association of Roman Law of the Argentine Republic, vol. VII General Roca, Río Negro, Argentina: Publifadecs, 2013.

[55] Fernández Sesarego, C., The person to be born in Vélez Sársfield, Code and the Peruvian Civil.

[56] Code of 198 in Annals of the National Academy of Law and Social Sciences of Córdoba, Córdoba, 2000.

[57] García del Corral, I., Body of Roman Civil Law, published by brothers Kriegel, Hermann and Osenbrugger, Barcelona: Jaime Molinas, 1892.

[58] Gracia, D., The embryo statute in Assisted Human Procreation: technical, ethical and legal aspects, Madrid: Eudema, 1991. 
[59] International treaties and documents, Buenos Aires: de Zavalía Víctor, 2001

[60] Irigoyen Troconis, M. P., Paulo, J., Sentences to his son, Mexico: Institute of Legal Investigations-Inst Of Philological Investigations, 1994.

[61] Judicial, C. d., Center of Judicial Information. Obtained from the Center of Judicial Information: http://elpais.cij.gov.ar/nota-6807-Niegan tratamiento-defertilizacion-asistida-por-no estar-incluida-en-lasprestaciones-de-la-obra-social-.html, August 7, 2016.

[62] Mainz, C., Course of Roman Law, tr. A. J. Pou and Ordinas, Barcelona: Molima, 1892.

[63] Mazzinghi, J., A brief reflection on in vitro fertilization in The Law doctrine section, Buenos Aires, 1978-C.

[64] Nation. Obtained from the Nation: http://www.nacion.com/sucesos/Voto-mayoria-SalaCuarta_0_42217799. html, March 15, 2001.

[65] Nor the astern National University. Obtained from Nor the astern National University: http//www.fai.unne.edu.ar/bioética/genética, March 12, 2011.

[66] Ortolán, M., Institutions of the Emperor Justinian, Madrid: Francisco Pérez de Anaya and Francisco Pérez Rivas, 1912.

[67] Project of Civil Code of 1998, Tucumán: Centro Editorial Fundación Miguel Lillo, 1999.

[68] Rabinovich, R., on/preventive measures, in ED-185-412, Buenos Aires, 1999.

[69] Rabinovich, R., on/preventive measures, The Law 2001-C824, Buenos Aires, 2001.

[70] Rabinovich, R., on/preventive measures, J. A. 2000-III-630, Buenos Aires, 2009.

[71] Ratzinger, J., Instructions on the respes nascendo human life and the dignity of procreation, in Congregation for the Doctrine of Faith. Buenos Aires: Paulinas, 1987.

[72] Reale, M., Tridimensional theory of law, Madrid: Tecnos, 1997.

[73] Religionennavarra. wordpress. Obtained from religionennavarra. wordpress: https://religionennavarra.wordpress.com/2011/10/20/historicoreconocimiento-por-el-tribunal-europeo-.

[74] de-justicia-del-embrion-humano-desde-la-fecundacion/, August 7, 2016.

[75] Rinaldi, N., The personality of the one whoistobeborn. (Romanistic Roots of art. 70 ofthe Civil Code), in ED T-149, Buenos Aires.

[76] Rivera, J. C., Institutions of Civil Law, general part., volume I, 4th updated and extended ed., Buenos Aires: Abeledo Perrot, 1994.

[77] Romeo Casabona, C., Law and bioethics before the limits of human life, Madrid: Center of Studies Ramón Areces, 1994.

[78] Schipani, S., Civil Cod of the Argentine Republic 2007 translated by Ildefonso García del Corral from The Roman sources cited by Dalmacio Vélez Sársfield, Buenos Aires: Rubinzal Culzoni, 2007.

[79] Sgreccia, Elio, Manual of Bioethics Institute of Humanities in Health Sciences, Mexico, Diana, 1996.

[80] Spanish-American Congress of Family Law, conclusions, year VII, No 7, Cáceres, Spain, 1987.

[81] Tertuliano, Opera de anima, Madrid: Akal, 2001.

[82] Vila Coro, M. Introduction to Biojuridical Science, Madrid: Complutense University of Madrid, 1995.

[83] Zavala de González M., Abortion, person to be born and right to life in the law D-1126, Buenos Aires, 1983. 